\title{
PERAN ” EKA LAK THAI” DALAM DEMOKASI DI THAILAND
}

\author{
Anna Yulia Hartati \\ Dosen Fakultas Ilmu Sosial dan Ilmu Politik, Jurusan Hubungan Internasional, \\ Universitas Wahid Hasyim Semarang \\ Jalan Menoreh Tengah X/22 Sampangan, Semarang, 50236 \\ Email : annayuliahartati@gmail.com
}

\begin{abstract}
This article describes the Role of "Eka Lak Thai" in the development of democracy in Thailand. The author uses qualitative research methods, where the author makes a description, description or painting systematically, factually, accurately about the facts, the properties and relationships between phenomena that are investigated through literature. Thais, Buddhists and Kings are an inseparable part of Thai society which is dictated in the constitution. This has caused democracy in Thailand to be carried out autonomously not absolutely because there is no separation between religion and state, making it difficult for the implementation of democracy. Thai democracy is only ceremonial because it does not open space for freedom of opinion, because the existing tradition is not just a social attribute that can be easily accepted, but the existence of state convictions in Thailand has hardened and become a political identity that fills all space, both political space and social space society.
\end{abstract}

Keywords: Thai Democracy, Eka Lak Thai, Political Identity

\section{Pendahuluan}

Thailand merupakan negara yang dalam sejarahnya tidak pernah dijajah sehingga Thailand memiliki kekhasan dan kekhususan tersendiri yang tidak sama seperti negara lain di daerah semenanjung atau di Asia Tenggara pada umunya. Masyarakat Thailand sering di sebut dengan sebutan orang Thai, atau juga dapat di sebut orang Siam, namun sebutan yang lebih popular bagi orang Thailand adalah Thai karena lebih pada pertimbangan etnies Thai dalam bahasa Thai berarti "orang bebas" Asal-usul orang Thai, memiliki ciri-ciri fisik yang tidak jauh berbeda dengan orang China, D.G.E. Hall sepakat mengisahkan perihal tanah asal orang Siam di Asia Tengah. Dipercaya bahwa sekitar 7000 tahun yang dahulu mereka mendiami kawasan pegunungan Altai (Mongolia) dan sekitarnya 2500 tahun kemudian berkembang hijrah ke selatan yang lebih subur . ${ }^{1}$

Namun seiring dengan kemajuan peradaban yang di dalangi oleh ilmu pengetahuan, dunia semakin sempit dan tidak lagi di batasi oleh ruang dan waktu, orang dari wilayah tertentu dapat melakukan kunjungan ke negara lain serta dapat membangun kerjasama yang saling menguntungkan dimana ada tukar menukar

\footnotetext{
${ }^{1}$ (www.pekemas.org).di akses pada tanggal 20 April 2018 pada pukul 02.20 wib
} 
(ekspor-import) barang atau pertukaran peradaban maka influence kemajuan dari negara yang lebih maju akan mempengaruhi negara yang lemah dalam teknologi atau peradaban maka sistem pemerintahan aristokrasi yang menjadi model pemerintahan di kerajaan Thailand pun mulai mengalami pergeseran.

Kondisi pergeseran ini adalah bagian dari spectrum politik yang sukar untuk diduga, meskipun begitu, dalam system politik modern, demokratis, dan rasional selalu ada semacam ketertebakan (predictable) politik dibandingkan dengan system politik tadisional. ${ }^{2}$ Hal ini mendorong Thailand untuk memikirkan design politik yang tepat bagi orang Thai dimana budaya dan tradisi tidak akan dimusnahkan tetapi juga mereka pun diharapkan untuk menyesuaikan diri dengan kemajuan peradaban di negara-negara maju yang menerapkan sistem pemerintahan yang demokratis.

Karena bagi orang Thai ada tiga hal yang suci atau yang sering disebut "eka lak thai" yakni : Bangsa Thai, Raja, dan Buddha, sehingga perlu pemikiran yang tepat dalam melihat penerapan demokrasi di Thailand karena suatu sisi demokrasi hadir untuk memberikan ruang bagi peran rakyat dalam pemerintahan namun di sisi lain bagi Thailand raja memiliki peran yang sangat penting dalam sistem politik Thailand. ${ }^{3}$ Bagaimanakah peran "Eka Lak Thai" dalam perkembangan demokrasi di Thailand?

\section{Metode Penelitian}

\section{D.1. Tipe Penelitian}

Penelitian bersifat deskriptif sebagai upaya menggambarkan apa yang sebenarnya terjadi dengan menggambarkan fakta-fakta dan memberikan data yang akurat dan tepat. Hal ini dilakukan untuk menggambarkan tentang Peran "Eka Lak Thai dalam Demokrasi Di Thailand.

\section{D.2. Teknik Analisis Data}

Penelitian ini menggunakan data sekunder yang dikumpulkan dari studi literatur, situs-situs internet, terbitan institusi, jurnal, artikel dari koran dan majalah, working paper, serta pidato dan presentasi. Dalam menganalisis, data yang telah terkumpul diolah dengan metode kualitatif tanpa pengukuran secara kuantitatif atau uji statistik. Langka logika yang dapat ditempuh adalah gabungan langkah logika

\footnotetext{
${ }^{2}$ Bambang Cipto, Hubungan Internasional di Asia Tenggara: Teropong Terhadap Dinamika, Realitas, dan Masa Depan, Pustaka Pelajar., Yogyakarta, 2007, hlm 107

${ }^{3}$ Bangkok Post, 3 Juli 2011, diakses pada tanggal 20 April 2018 pada pukul 02.20 wib
} 
deduktif maupun induktif, yaitu dimulai dari preposisi umum menuju yang khusus, begitu pula sebaliknya.

\section{Pembahasan}

\section{A. Peran Raja (Bhumibol Adulyadej) di dalam Perpolitikan Thailand}

Dalam melihat dinamika perpolitikan Thailand, Monarki atau khususnya Raja menjadi satu hal yang tidak dapat dikesampingkan. Faktor historis Thailand yang pernah memiliki sistem pemerintahan monarki absolut merupakan salah satu hal utama yang menyebabkan terlibatnya Raja di dalam perpolitikan Thailand sampai saat ini. Walaupun kini sistem pemerintahan Thailand telah menjadi monarki konstitusional tidak semata-mata peran Raja dalam perpolitikan dihapuskan seluruhnya. Raja yang seharusnya hanya melakukan fungsi seremonial tetap memainkan peranan penting dalam setiap aktivitas politik yang berlangsung di Thailand. $^{4}$

Peran penting Raja di dalam perpolitikan Thailand memiliki basis kuat yaitu legitimasi dari seluruh lapisan masyarakat Thailand. Dengan dimilikinya legitimasi yang kuat, akan lebih mudah bagi Raja Thailand dalam bertindak maupun mengeluarkan perintah. Berdasarkan konsep sumber legitimasi pemimpin menurut Ramlan Surbakti yang telah dijelaskan di bagian kerangka konsep, sosok Raja di Thailand memenuhi seluruh bentuk sumber legitimasi yang ada. Terkait dengan sumber legitimasi tradisional, Raja Bhumibol Adulyadej selain merupakan anak dari Raja terdahulunya, kepercayaan masyarakat Thailand akan nilai dalam agama Budha yang menyatakan bahwa Raja adalah reinkarnasi dari Dewa menjadikan Raja sebagai sosok yang dipercaya mampu dan wajib melindungi mereka. Hal ini akhirnya menciptakan rasa patuh dan setia kepada Raja bagi seluruh masyarakat Thailand.

Sumber legitimasi yang kedua yaitu legitimasi ideologi terwujud dalam kepercayaan Thailand akan The Holy Trinity atau segitiga suci yang menempatkan Raja di puncak segitiga tersebut. Dengan Raja berada di posisi teratas, dibutuhkan penopang posisi Raja tersebut yang salah satunya adalah agama Budha itu sendiri. Sumber legitimasi selanjutnya yaitu legitimasi institusional, dalam hal ini peran Raja dalam politik telah diatur di dalam konstitusi tahun 1997 Thailand. Raja dalam hal ini berwenang untuk menyetujui atau menolak aksi kudeta maupun membubarkan

\footnotetext{
${ }^{4}$ Murizio Peleggi, 2007, Thailand: The Worldly Kongdom, London: Reaktion Books LTd, hal 67
} 
parlemen. Dan terkait sumber legitimasi terkahir yaitu kemampuan pribadi, Raja Thailand, khususnya Bumibol Adulyadej, merupakan sosok yang tidak hanya mahir dalam memimpin rakyat namun juga mahir dalam memainkan alat musik, membuat lagu, melukis dan bahkan mahir dalam bidang fotografi. ${ }^{5}$

\section{Peran Bangsa Thai dan Buddha dalam perkembangan demokrasi}

Thailand merupakan negara yang dalam sejarahnya tidak pernah dijajah sehingga Thailand memiliki kekhasan dan kekhususan tersendiri yang tidak sama seperti negara lain di daerah semenanjung atau di Asia Tenggara pada umunya. Masyarakat Thailand sering di sebut dengan sebutan orang Thai, atau juga dapat di sebut orang Siam, namun sebutan yang lebih popular bagi orang Thailand adalah Thai karena lebih pada pertimbangan etnies Thai dalam bahasa Thai berarti "orang bebas" Asal-usul orang Thai, memiliki ciri-ciri fisik yang tidak jauh berbeda dengan orang China, D.G.E. Hall sepakat mengisahkan perihal tanah asal orang Siam di Asia Tengah. Dipercaya bahwa sekitar 7000 tahun yang dahulu mereka mendiami kawasan pegunungan Altai (Mongolia) dan sekitarnya 2500 tahun kemudian berkembang hijrah ke selatan yang lebih subur. ${ }^{6}$

Pemikiran diatas dapat membenarkan apabila orang Thai berasal dari Mongolia, karena ciri fisik turut mendukung namun yang menjadi persoalan yang perlu di cermati adalah relief tulisan yang jauh berbeda serta bahasa yang dipakai juga sangat jauh berbeda asumsi ini dikuatkan oleh George Coedes bahwa masuknya secara lamban dan boleh jadi yang sudah kuno, sepanjang sunagi-sungai berhubungan dengan pergeseran umum penduduk dari utara ke selatan yang menjadi ciri terbentuknya kependudukan di semenanjung Indochina. ${ }^{7}$

Masyarakat Thai memiliki cirri - ciri rambut yang hampir sama dengan orang Mongolia yakni membiarkan rambutnya panjang sebagaimana di tuliskan oleh Anthony Reid bahwa; memperlakukan bagian tubuh yang paling beragam yakni rambut, pria dan wanita tidak begitu dibedakan dalam hal gaya rambut, bagi keduanya rambut merupakan suatu lambang serta petunjuk diri yang sangat menentukan. Oleh sebab itu

\footnotetext{
5 Kevin Hewison, “A book, The King and 2006 Coup”, Journal of Contemporary Asia, (January 2002), hlm.196

6 Ellen London, 2008, Thailand Condensed: 2000 years of history and culture., Singapore: Marshall Cavendish Editions, hal 67

7 George Coedes, World Heritage Encyclopedia, Project Gutenberg Self Publishing Press, Cambodia, hal 56
} 
pola yang berlaku hingga kurun niaga tampaknya ialah didorongnya pria dan wanita untuk menumbuhkan rambut sepanjangnya dan selebat mungkin. ${ }^{8}$

Dalam hal yang lain bahwa banyak orang China atau orang Thai yang rambutnya di potong seperti para Saolin atau Bhiksu yang memiliki ciri-ciri seluruh rambutnya di potong sehingga yang tampak hanya kulit kepala saja, sepertinya pilihan ini khusus atau bagian dari ciri atau peran yang di jalankan. Menurut Anthony Reid bahwa pilihan diatas dengan memotong seluruh rambut merupakan pengorbanan diri dari pada pertanda pengekangan gairah seksual atau pengebirian, seperti yang pernah dikemukakan (Berg 1951; Leach 1958), Alcina (1668A: 18) menulis tentang kaum wanita Filipina, "sakit terberat yang bisa mereka rasakan ialah jika rambutnya diambil atau dipotong. Maka untuk menunjukan kesedihan yang mendalam mereka memotong rambut... suatu tanda bahwa mereka berkabung atas kematian orang tua atau suami yang dicintai.... Untuk suatu motif keagamaan atau menyatakan selamat tinggal pada keduniaan". 9 sebagaimana orang Thai dengan para bikkhunya yang memakai jubah serba kuning dengan kepala digundulkan. Dan motif pemotongan yang dilakukan di orang Thai lebih pada motif keagamaan atau menyatakan selamat tinggal pada keduniaan. Dan pilihan ini membuat mereka harus memiliki ciri atau perbedaan dari masyarakat kebanyakan. Thailand dalam sejarah merupakan merupakan jaringan dari aristokrasi dari Mongol, dimana Mongol mengontrol semua kelas sosial, "prajurit atau kaum setia yang merupakan insane bebas, rakyat biasa, dijadikan budak.

Salah satu tokoh yang bernama Ramkhamhaeng yang memiliki hubungan baik dengan Mongol dan menjadi bagian dari aristokrasi Mongol berhasil meraih semacam hegemoni atas sejumlah suku Thai akhirnya Ramkhamhaeng adalah pemimpin dan raja yang berkuasa penuh atas semua orang Thai. ${ }^{10}$.Dengan adanya pemimpin ini membuat orang Thai memiliki penguasa dan tunduk terhadap penguasa tersebut, daerah penaklukannya merupakan bagian dari kekuasaannya sehingga memenuhi syarat untuk mandiri sebagai sebuah kerajaan (negara) karena ada wilayah kekuasan (geografis), pemerintahan, dan rakyat, dan dari keturunan Ramkhamhaeng lah kerajaan Thai

\footnotetext{
${ }^{8}$ Anthony Reid, A History of Southeast Asia: critical Crossroads (Blackwell History of the world), Wiley Blackwell, 2015, hal 78

9 Thailand History. Diakses melalui http://www.thaiembassy.at/index.php/about-thailand/thailands-history, diakses pada 30 Oktober 2016

${ }^{10}$ CFR.2015.Thailand : Democratic Failure - It's Lessons Middle East. Diakses melalui http://www.cfr.org/thailand/thailand-democratic-failure-its-lessons-middle-east/p24485, diakses tanggal 20 Oktober 2018, pukul 05.00 Wib
} 
terbentuk. Kepemimpinan yang dipimpin oleh kerajaan turun temurun dan menjadi penentu bagi kerajaan hingga terbentuknya Thailand sebagai sebuah negara.

Namun seiring dengan kemajuan peradaban yang di dalangi oleh ilmu pengetahuan, dunia semakin sempit dan tidak lagi di batasi oleh ruang dan waktu, orang dari wilayah tertentu dapat melakukan kunjungan ke negara lain serta dapat membangun kerjasama yang saling menguntungkan dimana ada tukar menukar (ekspor-import) barang atau pertukaran peradaban maka influence kemajuan dari negara yang lebih maju akan mempengaruhi negara yang lemah dalam teknologi atau peradaban maka sistem pemerintahan aristokrasi yang menjadi model pemerintahan di kerajaan Thailand pun mulai mengalami pergeseran.

Kondisi pergeseran ini mendorong Thailand untuk memikirkan design politik yang tepat bagi orang Thai dimana budaya dan tradisi tidak akan dimusnahkan tetapi juga mereka pun diharapkan untuk menyesuaikan diri dengan kemajuan peradaban di negara-negara maju yang menerapkan sistem pemerintahan yang demokratis.

\section{Doktrin Eka Lak Thai dalam perkembangan demokrasi Thailand}

Hubungan raja dan orang Thai atau masyarakat Thailand begitu kuat dan tak mungkin dipisahkan karena merupakan bentuk turunan dari kepercayaan tradisional Thailand, raja di tempatkan sebagai inti dari doktrin Ekalak Thai. Sedangkan nilai-nilai demokrasi lebih merunut pada nilai-nilai kontemporer yang lebih mengacu pada budaya eropa atau barat (AS). Pemikiran Plato tentang negara memiliki kemiripin dengan apa yang dianut oleh kerajaan Thailand menurut Plato negara ideal menganut prinsip mementingkan kebajikan (virtue). Kebajikan menurut Plato adalah pengetahuan. Sehingga menurut Plato negara yang ideal atau negara yang terbaik bagi manusia adalah negara yang penuh kebajikan di dalamnya. Mereka yang berhak menjadi penguasa hanyalah mereka yang mengerti sepenuhnya prinsip kebajikan ini. Plato menyebut negarawan seperti itu seorang raja-filsuf - the philosopher king. ${ }^{11}$ Pemikiran Plato menguatkan apa yang menjadi tradisional pemahaman masyarakat Thailand dalam diri seorang raja karena bagi orang Thai, kedudukan raja tidak hanya diatur formal dalam konstitusi tetapi lebih pada nilai-nilai tradisional yang diyakini seperti keberadaan raja sebagai Bodhisattva pemilik kebajikan tertingi, dipercaya sebagai reinkarnasi dari seseorang yang pada masa lalunya memiliki pahala yang sangat tinggi.

\footnotetext{
${ }^{11}$ http://www.politik.lipi.go.id/in/kolom/politik-internasional/361-jalan-panjang-demokrasi-th ailand-.html diakses pada tanggal 12 Oktober 2018 pada pukul 03.00 wib
} 
Pemikiran bahwa sumber kabajikan hanya ada pada raja karena reinkarnasi merupakan sesuatu yang kuat sehingga sebagai pelindung bagi Buddihsm dan Sangha dan keduanya merupakan sumber legitimasi dari raja, sehingga raja menjadi symbol pemersatu dan symbol idnetitas bangsa keberadaan ini menunjukan bahwa keberadaan raja adalah mutlak sehingga model pemerintahannya adalah monarkhi absolute yang kemudian pada tahun 1932 merupakan titik awal dimulainya demokrasi di Thailand sehingga adanya Demokrasi di Thailand.

Proses demokrasi di awali dengan proses kudeta untuk membatasi kekuasaan raja dan mengikut sertakan sipil (masyarakat) dalam menjalankan pemerintahan. Penerapan demokrasi bagi masyarakat Thailand sejatinya bertolak belakang dengan nilai-nilai tradisonalnya karena ada spirit demokrasi yang sebetulnya tidak sejalan dengan nilai tradisional Thailand.Esensi demokrasi adalah bagaimana peran maksimal dari rakyat, dimana kedaulatan atau kekuasaan oleh rakyat, Abraham Lincoln menguraikan bahwa pengertian kekuasaan rakyat itu dalam slogan yang sangat ringkas, yaitu "from the people, by the people, and for the people, yang kesemuanya itu berintikan ide "rule by the people". 12

Pemikiran ini apakah sejalan dengan nilai - nilai tradisional Thai yang mendaulatkan kekuasaan itu ada pada raja dimana raja adalah inti atau obyek sembahan rakyat Thailand apa yang menjadi keputusan raja merupakan amanah bagi rakyat Thailand, dimana kasus PM. Thaksin yang secara demokratis mendapatkan dukungan mayoritas dari rakyat dan memilih Partai yang didirikan Thaksin yakni Thai Rak Thai menang di parlemen sehingga secara demokratis maka Thaksin mendapatkan kedaulatan dari rakyat.

Mengacu pada "dari rakyat" maka akan menunjuk adanya suatu pemilihan umum yang bebas atau kebebasan memilih yang dimiliki secara sama oleh seluruh rakyat, kondisi ini dengan sendirinya Thaksin terpilih secara demokratis, namun kuatnya tekanan perlawanan oleh lawan politik dengan masing-masing menghadirkan masa turun ke jalanan membuktikan demokratisasi yang tumbuh di Thailand.

Kondisi ini tidak sertamerta menyelesaikan persoalan demokrasi karena kedua pihak yang tidak mengalah dan akhirnya kekuasaan Rajalah yang menyelesaikan

\footnotetext{
${ }^{12}$ http://politik.kompasiana.com/2010/05/21/manajemen-anti-kudeta-di-thailand-belajar-dari-i ndonesia-146693.html di akses pada tanggal 12 Oktober 2018, pada pukul 02.05 wib
} 
persolan dengan memerintahkan PM. Thaksin untuk melepaskan jabatan, dengan demikian seluruh rakyat tunduk dan taat pada apa yang diperintahkan oleh Raja. Kata “oleh rakyat" sering dipahami lain yakni kepemimpinan dipimpin beramai-ramai oleh rakyat, apa jadinya jika sebuah pemerintahan di perintah oleh beribu-ribu orang sehingga oleh rakyat di sini yakni diwakilkan kepada wakil-wakil yang dipilih melalui pemilu, di Thailand wakil-wakil itu ada di parlemen karena mereka diusung oleh partai politik sebagai sarana untuk memudahkan pemilihan. Namun bukan berarti keputusan mutlak di tangan wakil-wakil rakyat tersebut tetapi tetap keputusan akhir ada pada Raja. Jika pemikiran "oleh rakyat" apakah dengan keberadaan nilai-nilai orang Thai dimana ketaatan pada raja, yakni setiap masyarakat Thai harus tunduk dan taat kepada keputusan raja, semua berkewajiban untuk menegakan keputusan Raja, apabila mengacu bahwa keputusan taatnya rakyat pada raja tanpa perlawanan adalah sesuatu yang baik maka hal tersebut dapat di sebut "democratic pradoksal" karena di suatu sisi telah memenuhi varibel suara terbanyak karena mayoritas orang Thai akan mematuhi keputusan raja yakni dukungan kepatuhan sebai bentuk suara terbanyak namun dilain pihak keputusan tersebut nyaris tanpa celah untuk dikritisi atau di perdebatkan sebagaimana yang ditawarkan demokrasi deliberative karena bagi rakyat suara raja dianggab suara dewa yang tidak memiliki kemungkinan salah/dosa sehingga sudah pasti mutlak benar. Dan keputusan Raja bertujuan untuk stabilitas dan kedamaian orang Thai karena Raja ingin adanya ketentraman pemikiran orang Thai diperhadapkan antara peradaban tradisional dan peradaban modern dimana mereka menerima demokrasi sebagai bagian dari sistem pemerintahan Thailand.

Orang Siam atau Thai yang kebanyakan menganut agama Buddha akan menghormati apa yang menjadi putusan raja, karena kepercayaan atas nilai-nilai tradisional yang dianut yakni peran tradisional raja, raja-raja Thailand percaya bahwa mereka adalah Bodhisattva dimana karena rasa kasihnya yang luar biasa ia meninggalkan nirvana untuk menolong manusia, pemikiran keyakinan yang mereka miliki bahwa raja dalam setiap keputusan atau kebijakannya merupakan inspirasi yang merupakan apa yang dikehendaki sang Ilahi dan di percaya demi kebaikan bersama.

Dilain pihak demokrasi hadir dari barat dengan nilai - nilai yang menjamin individual yang bertolak belakang dengan apa yang dijalankan di Thailand, nilai-nilai demokrasi sebagaimana disederhankan oleh Samuel Huntington bahwa; sebuah sistem politik disebut demokratis bila "para pembuat keputusan kolektif yang paling kuat dalam sistem itu dipilih melalui pemilihan umum yang adil, jujur, dan berkala dan 
didalam sistem itu para calon bebas bersaing untuk memperoleh suara dan hampir semua penduduk dewasa berhak memberikan suara. ${ }^{13}$

Hubungan raja dan orang Thai atau masyarakat Thailand begitu kuat dan tak mungkin dipisahkan karena merupakan bentuk turunan dari kepercayaan tradisional Thailand, raja di tempatkan sebagai inti dari doktrin Ekalak Thai. Sedangkan nilai-nilai demokrasi lebih merunut pada nilai-nilai kontemporer yang lebih mengacu pada budaya eropa atau barat (AS).

Pemikiran Plato tentang negara memiliki kemiripin dengan apa yang dianut oleh kerajaan Thailand menurut Plato negara ideal menganut prinsip mementingkan kebajikan (virtue). Kebajikan menurut Plato adalah pengetahuan. Sehingga menurut Plato negara yang ideal atau negara yang terbaik bagi manusia adalah negara yang penuh kebajikan di dalamnya. Mereka yang berhak menjadi penguasa hanyalah mereka yang mengerti sepenuhnya prinsip kebajikan ini. Plato menyebut negarawan seperti itu seorang raja-filsuf - the philosopher king. ${ }^{14}$ Pemikiran Plato menguatkan apa yang menjadi tradisional pemahaman masyarakat Thailand dalam diri seorang raja karena bagi orang Thai, kedudukan raja tidak hanya diatur formal dalam konstitusi tetapi lebih pada nilai-nilai tradisional yang diyakini seperti keberadaan raja sebagai Bodhisattva pemilik kebajikan tertingi, dipercaya sebagai reinkarnasi dari seseorang yang pada masa lalunya memiliki pahala yang sangat tinggi. ${ }^{15}$

Pemikiran bahwa sumber kabajikan hanya ada pada raja karena reinkarnasi merupakan sesuatu yang kuat sehingga sebagai pelindung bagi Buddihsm dan Sangha dan keduanya merupakan sumber legitimasi dari raja, sehingga raja menjadi symbol pemersatu dan symbol idnetitas bangsa keberadaan ini menunjukan bahwa keberadaan raja adalah mutlak sehingga model pemerintahannya adalah monarkhi absolute yang kemudian pada tahun 1932 merupakan titik awal dimulainya demokrasi di Thailand sehingga adanya Demokrasi di Thailand.

Proses demokrasi di awali dengan proses kudeta untuk membatasi kekuasaan raja dan mengikut sertakan sipil (masyarakat) dalam menjalankan pemerintahan. Penerapan demokrasi bagi masyarakat Thailand sejatinya bertolak belakang dengan nilai-nilai tradisonalnya karena ada spirit demokrasi yang sebetulnya tidak sejalan dengan nilai tradisional Thailand. Esensi demokrasi adalah bagaimana peran maksimal dari rakyat,

\footnotetext{
${ }^{13}$ Hendra Nurtjahjo, Filsafat Demokrasi, Bumi Aksara, Jakarta, 2008, hal 45

14 Ahmad Suhelmi, Pemikiran Politik Barat, Gramedia, Jakarta, 2007, hal 35

15 Ibid
} 
dimana kedaulatan atau kekuasaan oleh rakyat, Abraham Lincoln menguraikan bahwa pengertian kekuasaan rakyat itu dalam slogan yang sangat ringkas, yaitu "from the people, by the people, and for the people, yang kesemuanya itu berintikan ide "rule by the people".

Pemikiran ini apakah sejalan dengan nilai - nilai tradisional Thai yang mendaulatkan kekuasaan itu ada pada raja dimana raja adalah inti atau obyek sembahan rakyat Thailand apa yang menjadi keputusan raja merupakan amanah bagi rakyat Thailand, dimana kasus PM. Thaksin yang secara demokratis mendapatkan dukungan mayoritas dari rakyat dan memilih Partai yang didirikan Thaksin yakni Thai Rak Thai menang di parlemen sehingga secara demokratis maka Thaksin mendapatkan kedaulatan dari rakyat. ${ }^{16}$

Mengacu pada "dari rakyat" maka akan menunjuk adanya suatu pemilihan umum yang bebas atau kebebasan memilih yang dimiliki secara sama oleh seluruh rakyat, kondisi ini dengan sendirinya Thaksin terpilih secara demokratis, namun kuatnya tekanan perlawanan oleh lawan politik dengan masing-masing menghadirkan masa turun ke jalanan membuktikan demokratisasi yang tumbuh di Thailand.

\section{Kesimpulan}

Demokrasi di Thailand sejatinya hanyalah demokrasi prosedural yang di tafsirkan secara mayoritas mengabaikan kelompok particular dalam sebuah Negara, sehingga demokrasi Thailand tidak menjawab subtansi demokrasi, sehingga peluang yang perlu dilakukan adalah otonomi khusus demokrasi bagi kelompok particular yang membebaskan dan setara dengan masyarakat

Bangsa thai, budhis, dan raja yang merupakan bagian yang tidak terpisahkan dari masyarakat Thai terdoktrin dalam konstitusi hal ini menyebabkan demokrasi Thailand harus dilakukan secara otonom tidak berlaku mutlak karena tidak ada pemisahan antara agama dan Negara sehingga menyulitkan bagi penerapan demokrasi. Demokrasi Thailand hanyalah seremonial karena tidak membuka ruang bagi kebebasan berpendapat, karena tradisi yang ada bukan hanya sekedar atribut sosail yang dapat mencair, tetapi keberadaan keyakinan bernegara di Thailand telah mengeras dan menjadi identitas politik yang mengisi semua ruang baik itu ruang politik dan ruang sosial masyarakat.

16 Glassman, Jim, The Provinces Elect Governments, Bangkok Overthrows Them: Urbanity, Class, and Post-Democracy in Thailand, Urban Studies 47, Issue 6, 2010 


\section{Referensi}

Buckingham, W., Burnham, D., King, P.J., Hill, C., Weeks, M., Marenborn, J. (2011). The Philosophy Book. New York, NY: DK Publishing.

Cipto,Bambang Hubungan Internasional di Asia Tenggara: Teropong Terhadap Dinamika, Realitas, dan Masa Depan, Pustaka Pelajar., Yogyakarta, 2007

Glassman, Jim, The Provinces Elect Governments, Bangkok Overthrows Them:

Urbanity, Class, and Post-Democracy in Thailand, Urban Studies 47, Issue 6, 2010

Nurtjahjo, Hendra , Filsafat Demokrasi, Bumi Aksara, Jakarta, 2008

Suhelmi, Ahmad, Pemikiran Politik Barat, Gramedia, Jakarta, 2007 
Pye, L. (1996). Aspects of Political Development: An Analytic Study. Boston, MA: Little Brown.

Reid, Anthony, A History of Southeast Asia: critical Crossroads (Blackwell History of the world), Wiley Blackwell, 2015

\section{Dari jurnal online}

Homfeldt, H.G. and Reutlinger, C. (2008). Social Development. Social Work and Society International Online Journal, 6(2). Retrieved from http://www.socwork.net/sws/article/view/70/372

\section{Dari artikel online}

Kaplan, R.D. (2015, February 6). Asia's Rise Is Rooted in Confucian Values. Wall $\begin{array}{lll}\text { Street } \quad \text { Journal. } & \text { Retrieved }\end{array}$ http://www.wsj.com/articles/asias-rise-is-rooted-in-confucian-values-14232547 $\underline{59}$

Mahbubani, K. (2015, August 4). Why Singapore Is The World's Most Successful Society. Huffington Post. Retrieved from http://www.huffingtonpost.com/kishore-mahbubani/singapore-world-successful -society_b_7934988.html

Ministry of Foreign Affairs. (2012, December 6). Strait Times: Singapore Remains $5^{\text {th }}$ $\begin{array}{llll}\text { Least Corrupt } & \text { Country. } & \text { Retrieved }\end{array}$ http://www.mfa.gov.sg/content/mfa/media_centre/singapore_headlines/2012/20 1212/infocus_20121206.html

Sim, W. (2015, November 8). The race issue: How far has Singapore Come?. Strait Times. $\quad$ Retrieved from http://www.straitstimes.com/politics/the-race-issue-how-far-has-singapore-com $\underline{\mathrm{e}}$

Singapore National Library Board. (2004, December 18). Shared Values. Retrieved from http://eresources.nlb.gov.sg/infopedia/articles/SIP_542_2004-12-18.html

Teenhankee, J.C. (2007). The Political Aftermath of the 1997 Crisis: from Asian Values to Asian Governance? Retrieved from http://library.fes.de/pdf-files/bueros/singapur/04601/2007-2/teehankee.pdf
Weiming, T. (2016).
Confucianism.
Retrieved from

http://www.britannica.com/topic/Confucianism 
(www.pekemas.org).di akses pada tanggal 20 April 2018

Bangkok Post, 3 Juli 2011, diakses pada tanggal 20 April 2018 